\title{
Effect of Welding Heat Input on Microstructure and Properties of Coarse Grain Zone in Heat Affected Zone of Ultra-Low Carbon Bainitic Steel
}

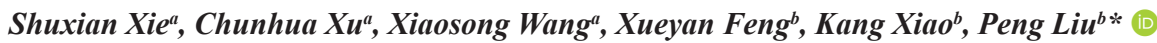 \\ ${ }^{a}$ Shandong CRRC Tongli steel structure Co. LTD, 250101, Jinan, China. \\ ${ }^{b}$ Shandong Jianzhu University, School of Materials Science and Engineering, 250101, Jinan, China.
}

Received: April 16, 2021; Revised: October 01, 2021; Accepted: October 21, 2021

\begin{abstract}
In order to explore the effect of different the welding heat input on microstructure and impact properties in coarse grain zone in heat affected zone (CGHAZ) of ultra-low carbon bainitic steel welded joint. In this paper, Gleeble-3500 thermal simulation testing machine was used to simulate different heat input, to study the effect of linear energy on the microstructure and impact toughness of the CGHAZ of Q420qEN steel joint. The scanning electron microscope (SEM), oscillographic impact microscope and transmission electron microscope (TEM) were used. The results show that the microstructure of CGHAZ is mainly the lath bainite and granular bainite. When the welding heat input is $30 \mathrm{~kJ} \bullet \mathrm{cm}-1$, the CGHAZ grains have obvious growth phenomenon. With the increase of the welding heat input, the grain size also grows. Meanwhile, as the welding heat input increases from $18 \mathrm{~kJ} \bullet \mathrm{cm}^{-1}$ to $30 \mathrm{~kJ} \bullet \mathrm{cm}^{-1}$, the impact toughness of the CGHAZ of joint increases first and then decreases at $-20^{\circ} \mathrm{C}$.
\end{abstract}

Keywords: ultra-low carbon bainitic steel; gleeble-3500; heat affected zone; microstructure; impact property.

\section{Introduction}

Ultra-low carbon Bainitic steel has important performance including the high strength, good impact toughness and weldability ${ }^{1}$. At present, it is internationally praised as the environmental protection green steel in the 21 st century, and it is widely used in oil and gas pipelines, heavy machinery, railway transportation and other aspects. In particular, the railway transport industry has a very prominent advantage due to the unbalanced economic development and uneven distribution. However, the railway operating condition is relatively poor, like supplies of railway freight need years of working in a relatively harsh environment operation. In addition, the steel structures of railway freight cars need to obtain high comprehensive performance, high performance and corrosion resistance, and low cost of ultra-low carbon bainite steel has been widely used in railway transportation industry and promotion ${ }^{2}$.

In the 1960 s, it began to study ultra-low carbon bainite steel, and it was applied and developed including high-pressure pipelines. And then, it gradually applied in large mechanical components, ships and Marine facilities. At present, the United States and Japan and other countries paid more attention to the research of ultra-low carbon bainite steel, and developed the extra-thick ultra-low carbon bainite steel for Bridges and buildings with tensile strength up to $590 \mathrm{MPa}^{3}$. Canada developed a kind of ultra-low carbon bainite steel for railway frog track. The microstructural and crystallographic characteristics of steel containing $0.26 \mathrm{wt} \%$ carbon, as well as the mechanical properties and fracture behavior were studied by Hamid Mousalou.

*e-mail: liupeng1286@163.com
The results showed that the subsequent austempering heat treatment at a lower temperature, immediately after partial bainite formation at a higher temperature, would replace the coarse austenite/martensite areas with much refined bainite consisting nanoscale plates of bainitic ferrite and filmy austenite which ultimately leads to the refinement of the bainitic microstructure. This microstructural modification, in addition to the increased yield strength, causes a significant increase in the impact fracture toughness of the multi-step austempered steels ${ }^{4}$.

At present, China's research on high strength ultra-low carbon bainitic steel has entered the mature stage, in which 400 700MPa steel has been able to meet the mass production, and applied to large structural facilities. Carbon content is extremely low, this kind of steel for low carbon bainite matrix, high strength and toughness of the alloy steel, through solid solution strengthening, grain refining strengthening ${ }^{5,6}$, dislocation strengthening methods such as strengthening and organization, have good welding technology and the ability of resistance to hydrogen induced cracking ${ }^{7,8}$, at the same time of guarantee good toughness and can guarantee high strength, steel weldability, able to meet the harsh conditions without preheating before welding and without heat treatment ${ }^{9}$. Jiang et al. ${ }^{10}$ analyzed that the ultra-low carbon bainitic steel has lower cold cracking sensitivity, and preheating temperature of $100^{\circ} \mathrm{C}$ can help completely eliminate cold cracks, generating good process weldability. The increase of preheating temperature can reduce the hardening degree of heat affected zone. The strength of welding joint decreases and hardness reduces when heat inputs increase, and excellent mechanical properties can be obtained when low welding 
heat inputs are used.Fine lath bainites of different orientations combined with a few granular bainites that effectively split the original coarse austenite grains are the foundation of good properties. Therefore, it is a new type of steel which can be combined with the traditional ferrite pearlite steel and martensitic quenched tempered steel.

The high-strength ultra-low carbon bainitic steel Q420qEN studied in this paper belongs to welding steel for construction machinery. At present, certain breakthroughs have been made in the aspects of composition design, processing technology, and microstructure control and strength and toughness properties. However, relatively few researches have been made on its weldability, and the influence of the welding heat input on the microstructure and properties of joints is extremely important. In this paper, Gleeble-3500 thermal simulation test machine was used to simulate the effects of different heat input on the microstructure and impact toughness of the coarse crystal area in the heat-affected welding zone. This study will provide an experimental basis for the selection of welding technological parameters of steel Q420qEN.

\section{Experimental}

The ultra-low carbon bainitic steel selected in this study is $420 \mathrm{MPa}$ weathering steel and the steel plate brand is Q420qEN. The steel plate with thickness of $15 \mathrm{~mm}$ is hot-rolled through a $50 \mathrm{Kg}$ vacuum furnace. The chemical composition is shown in Table 1.

The dimension of the steel plate is $80 \mathrm{~mm} \times 10.5 \mathrm{~mm} \times 10.5 \mathrm{~mm}$. For welding thermal simulation test, the shape dimensions are shown in Figure 1, and the thermal simulation experiment was carried out on Gleeble-3500 type. According to the actual welding heat affected zone, the coarse grain area was simulated with heating and cooling process, and the parameters are shown in Table 2. The welding heat input $(E)$ cover plate submerged arc welding (SAW) and fluxedcored arc welding (FCAW) range of process parameters ${ }^{11}$.

After the thermal simulation test, the metallographic samples were intercepted from the samples, and then mechanically ground and polished with $4 \%$ alcohol nitrate solution. The microstructure and fracture morphology were analyzed by field emission electron microscopy (SEM), and the internal structure of the microstructure was observed by transmission electron microscopy (TEM). After the thermal simulation test, the sample was selected along the rolling direction to intercept the $\mathrm{V}$-shaped notch impact pattern of $10 \mathrm{~mm} \times 10 \mathrm{~mm} \times 55 \mathrm{~mm}$. The notch direction was the direction of steel plate thickness. Under the condition of the test temperature of $-20^{\circ} \mathrm{C}$, the oscillogram impact test was carried out to obtain the oscillogram curve under different welding line energies.

\section{Results and Discussion}

\subsection{Microstructures}

Heat affected zone coarse grain zone (CGHAZ) is composed of lath bainite ferrite, granular bainite and lath bainite with strips or needles observed using a microscope, and the parallel bainite lamella has good comprehensive mechanical properties, such as high strength, hardness, toughness and wear resistance ${ }^{12,13}$. And the granular bainite is in ferrite matrix distribution of island, and the island group consists of martensite and retained austenite, also known as the M-A island ${ }^{14-16}$. M-A islands in granular bainite are disorderly arranged, long strip and sharp M-A islands are easy to cause stress concentration and crack initiation, and this structure should be controlled in the actual production welding process.

The main structures of CGHAZ are lath bainite, ferrite and granular bainite. The lath bainite is in the shape of strip or needle leaf, and it is composed of parallel bainite lamellae,

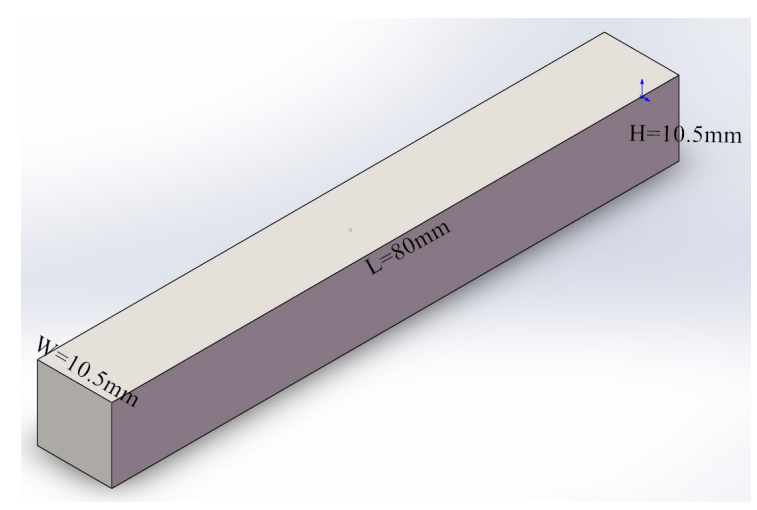

Figure 1. Shape and size of sample for Gleeble thermal simulation test.

Table 1. Chemical composition of Q420QEN steel.

\begin{tabular}{ccccccccccccc}
\hline \multicolumn{11}{c}{ Clement } \\
\hline $\mathrm{C}$ & $\mathrm{Si}$ & $\mathrm{Mn}$ & $\mathrm{P}$ & $\mathrm{S}$ & $\mathrm{Ni}$ & $\mathrm{Cr}$ & $\mathrm{Mo}$ & $\mathrm{Cu}$ & $\mathrm{Nb}$ & $\mathrm{Ti}$ & $\mathrm{Al}$ & $\mathrm{Bal}$ \\
\hline 0.056 & 0.31 & 1.27 & 0.0078 & 0.024 & 0.37 & 0.46 & 0.045 & 0.32 & 0.026 & 0.015 & 0.021 & $\mathrm{Fe}$ \\
\hline
\end{tabular}

Table 2. The process parameters of welding thermal simulation test.

\begin{tabular}{cccccc}
\hline \multirow{2}{*}{ Test specimens } & \multicolumn{4}{c}{ Parameters } \\
\cline { 2 - 6 } & $\begin{array}{c}\text { Linear } \\
\text { energy }\left(\mathrm{kJ} \cdot \mathrm{cm}^{-1}\right)\end{array}$ & Heating rate $\left({ }^{\circ} \mathrm{C} \cdot \mathrm{s}^{-1}\right)$ & $\begin{array}{c}\text { Preheating } \\
\text { temperature }\left({ }^{\circ} \mathrm{C}\right)\end{array}$ & $\begin{array}{c}\text { Peak } \\
\text { temperature }\left({ }^{\circ} \mathrm{C}\right)\end{array}$ & Cooling time $\left({ }^{\circ} \mathrm{C}\right)$ \\
\hline $\mathrm{A}$ & 18 & 100 & 100 & 1320 & 35.72 \\
\hline $\mathrm{B}$ & 24 & 100 & 100 & 1320 & 56.31 \\
\hline $\mathrm{C}$ & 30 & 100 & 100 & 1320 & 87.64 \\
\hline
\end{tabular}


which has good comprehensive mechanical properties such as high strength, hardness, toughness and wear resistance. In addition, the granular bainite consists of martensite and retained austenite, which is also called M-A island. The M-A islands in the granular bainite are disorderly arranged. The long and sharp M-A islands are easy to cause stress concentration and crack initiation. Therefore, the content of $\mathrm{M}-\mathrm{A}$ islands should be controlled in the actual production and welding process.

Different welding heat input can affect the microstructure of HAZ. Figure 2 shows the microstructure of CGHAZ under three groups of welding energy. In Figure 2a, it can be seen that when the welding heat input is $18 \mathrm{~kJ} \cdot \mathrm{cm}^{-1}$, the microstructure of CGHAZ is mainly the lath bainite and granular bainite, and the granular bainite and lath bainite are distributed alternately. In Figure $2 b$, it can be seen that when the welding heat input reaches $24 \mathrm{~kJ} \cdot \mathrm{cm}^{-1}$, the bainite in CGHAZ is regularly distributed in plate shape. However, when the welding heat input is increased to $30 \mathrm{~kJ} \cdot \mathrm{cm}^{-1}$, as shown in Figure 2c, the CGHAZ microstructure is mainly the granular bainite.

Figure 3 shows the TEM microstructure of the joint under different welding energy. The microstructure of the joint is composed of the granular bainite ferrite, lath bainite ferrite and M-A component. The morphology of CGHAZ at $18 \mathrm{~kJ} \cdot \mathrm{cm}^{-1}$ and $24 \mathrm{~kJ} \cdot \mathrm{cm}^{-1}$ are shown in Figure $3 \mathrm{a}$ and $3 \mathrm{~b}$, respectively. With the increase of the welding heat input, it can be seen that the microstructure is more uniform and refined, and the lath bainite is parallel to a certain orientation, and this is consistent with the microstructure by SEM analysis. Moreover, when the welding heat input increases from $24 \mathrm{~kJ} \cdot \mathrm{cm}^{-1}$ to $30 \mathrm{~kJ} \cdot \mathrm{cm}^{-1}$, the granular bainite ferrite dominates in CGHAZ, and the size and quantity of M-A increase significantly, and the grain size becomes more coarser.

\subsection{Oscillographic shock analysis}

In order to further study the influence of different the welding heat input on the impact toughness of CGHAZ, the oscillographic impact test was carried out. It can clearly reflect the energy change, fracture characteristics, crack growth rate and fracture morphology of CGHAZ at different stages. Figure 4 shows the oscillographic curve of CGHAZ of test steel with the welding heat input of $18 \mathrm{~kJ} \cdot \mathrm{cm}^{-1}$. In the beginning of crack initiation, it experiences the position of maximum load and the process of crack unstable propagation. In this process, the $\mathrm{Wi}$ is as the crack formation energy. After the crack instability propagation point is the crack propagation work (Wp), which corresponds to the crack radiation expansion area, fiber growth area and tear lip. And the $\mathrm{Wt}$ is the total impact energy, so it can be expressed as: $\mathrm{Wt}=\mathrm{Wi}+\mathrm{Wp}$.

The impact toughness test results are shown in Table 3 . It can be seen in Table 3 that when the welding heat input is $24 \mathrm{~kJ} \cdot \mathrm{cm}^{-1}$, the total impact energy of CGHAZ is the highest, which is $213 \mathrm{~J}$. When the heat input of crack formation energy is $30 \mathrm{~kJ} \cdot \mathrm{cm}^{-1}$, the total fracture energy is the lowest. Therefore, when the welding heat input is $24 \mathrm{~kJ} \cdot \mathrm{cm}^{-1}$, the
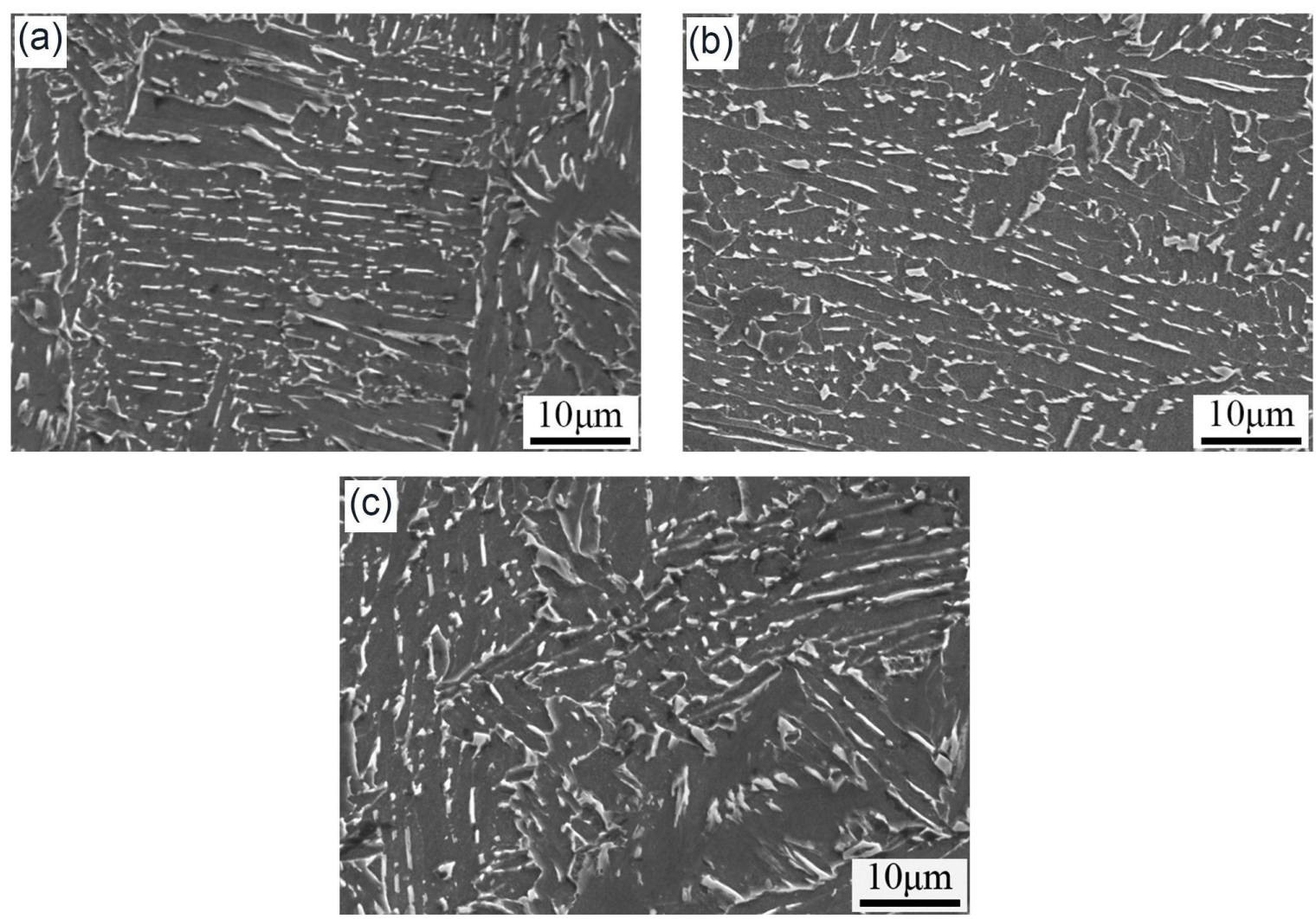

Figure 2. SEM morphology in CGHAZ of welded joint under different the welding heat input: (a) $18 \mathrm{~kJ} \cdot \mathrm{cm}^{-1}$, (b) $24 \mathrm{~kJ} \cdot \mathrm{cm}^{-1}$ and (c) $30 \mathrm{~kJ} \cdot \mathrm{cm}^{-1}$. 
Table 3. The process parameters of welding thermal simulation.

\begin{tabular}{ccccccc}
\hline & \multicolumn{6}{c}{ Parameters } \\
\cline { 2 - 7 } Test specimens & $\begin{array}{c}\text { Temperature } \\
\mathrm{T}\left({ }^{\circ} \mathrm{C}\right)\end{array}$ & $\begin{array}{c}\text { Total impact } \\
\text { energy Wt }(\mathrm{J})\end{array}$ & $\begin{array}{c}\text { Crack forming } \\
\text { energy Wi }(\mathrm{J})\end{array}$ & $\begin{array}{c}\text { Crack } \\
\text { propagation } \\
\text { energy Wp }(\mathrm{J})\end{array}$ & $\begin{array}{c}\text { Shear rate FA }(\%) \\
\text { Lateral } \\
\text { expansion value } \\
\text { LE }(\mathrm{mm})\end{array}$ \\
\hline $\mathrm{A}$ & -20 & 213 & 55 & 158 & 85 & 2.06 \\
\hline $\mathrm{B}$ & -20 & 152 & 54 & 98 & 40 & 1.96 \\
\hline $\mathrm{C}$ & -20 & 106 & 59 & 47 & 24 & 1.50 \\
\hline
\end{tabular}
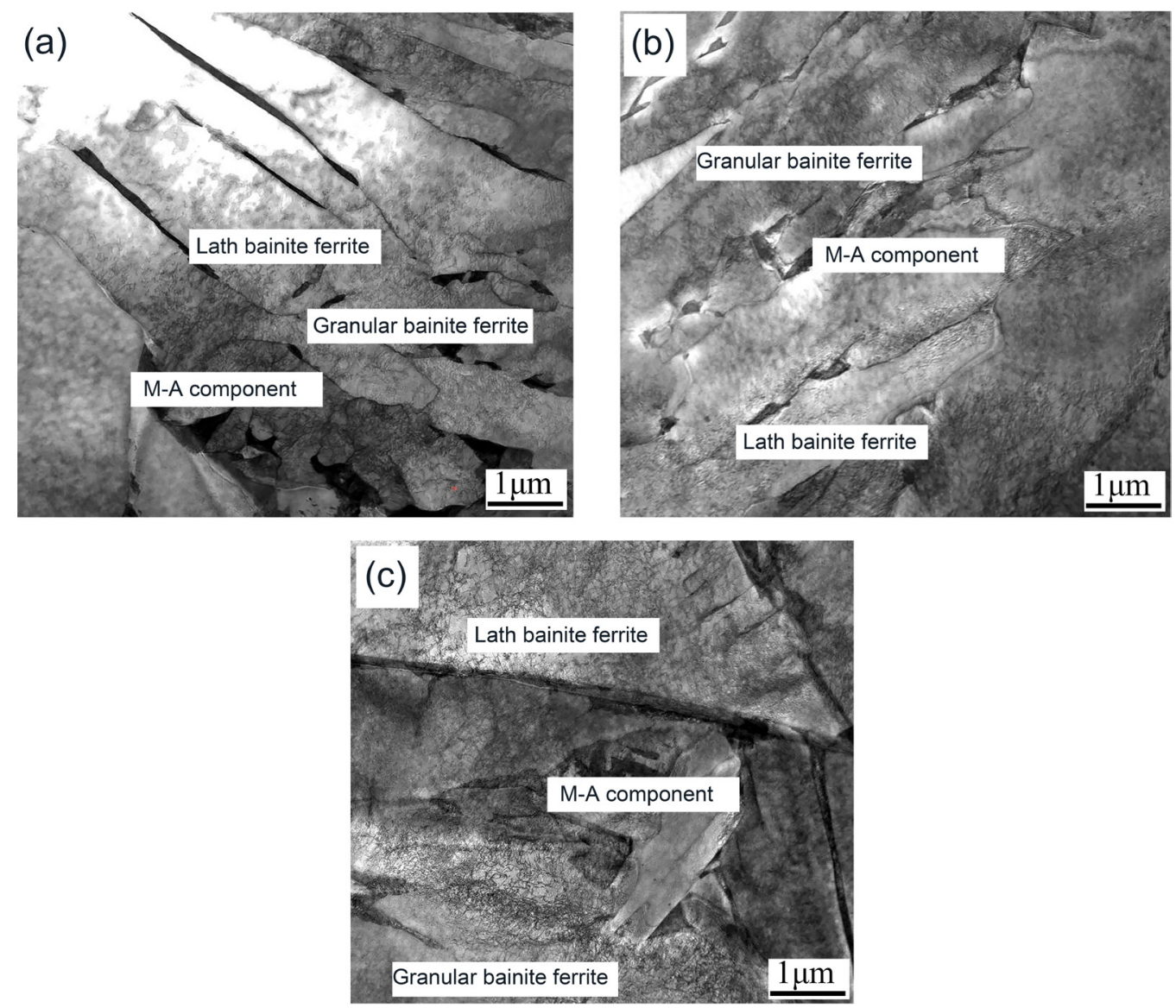

Figure 3. TEM morphology of CGHAZ joint under different the welding heat input: (a) $18 \mathrm{~kJ} \cdot \mathrm{cm}^{-1}$, (b) $24 \mathrm{~kJ} \cdot \mathrm{cm}^{-1}$ and (c) $30 \mathrm{~kJ} \cdot \mathrm{cm}^{-1}$.

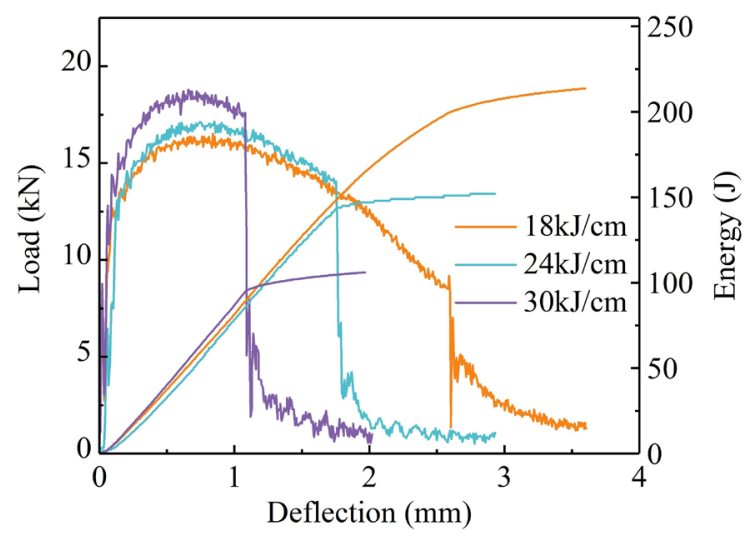

Figure 4. Oscillographic impact energy of test steel CGHAZ under different the welding heat input. impact toughness of the test steel is the best, followed by $18 \mathrm{~kJ} \cdot \mathrm{cm}^{-1}$, and the worst is at $30 \mathrm{~kJ} \cdot \mathrm{cm}^{-1}$.

Crack formation energy and crack growth energy can also reflect the difference of crack initiation resistance and crack propagation resistance of metal materials. It can be seen that the crack growth energy of three groups of different heat input is very little, but the difference of crack growth energy is large. When the welding heat input is $24 \mathrm{~kJ} \cdot \mathrm{cm}^{-1}$, the maximum crack growth energy is $153 \mathrm{~J}$, and the welding heat input is $18 \mathrm{~kJ} \cdot \mathrm{cm}^{-1}$, which is about $66 \%$ of that of $24 \mathrm{~kJ} \cdot \mathrm{cm}^{-1}$. When the welding heat input is $30 \mathrm{~kJ} \cdot \mathrm{cm}^{-1}$, it is about $33 \%$ of the welding heat input of $24 \mathrm{~kJ} \cdot \mathrm{cm}^{-1}$. Therefore, when the welding heat input is $24 \mathrm{~kJ} \cdot \mathrm{cm}^{-1}$, the crack growth resistance of the sample is the highest. When the impact sample is broken, the greater the impact energy, the greater the shear section ratio and lateral expansion value. It can be seen that 

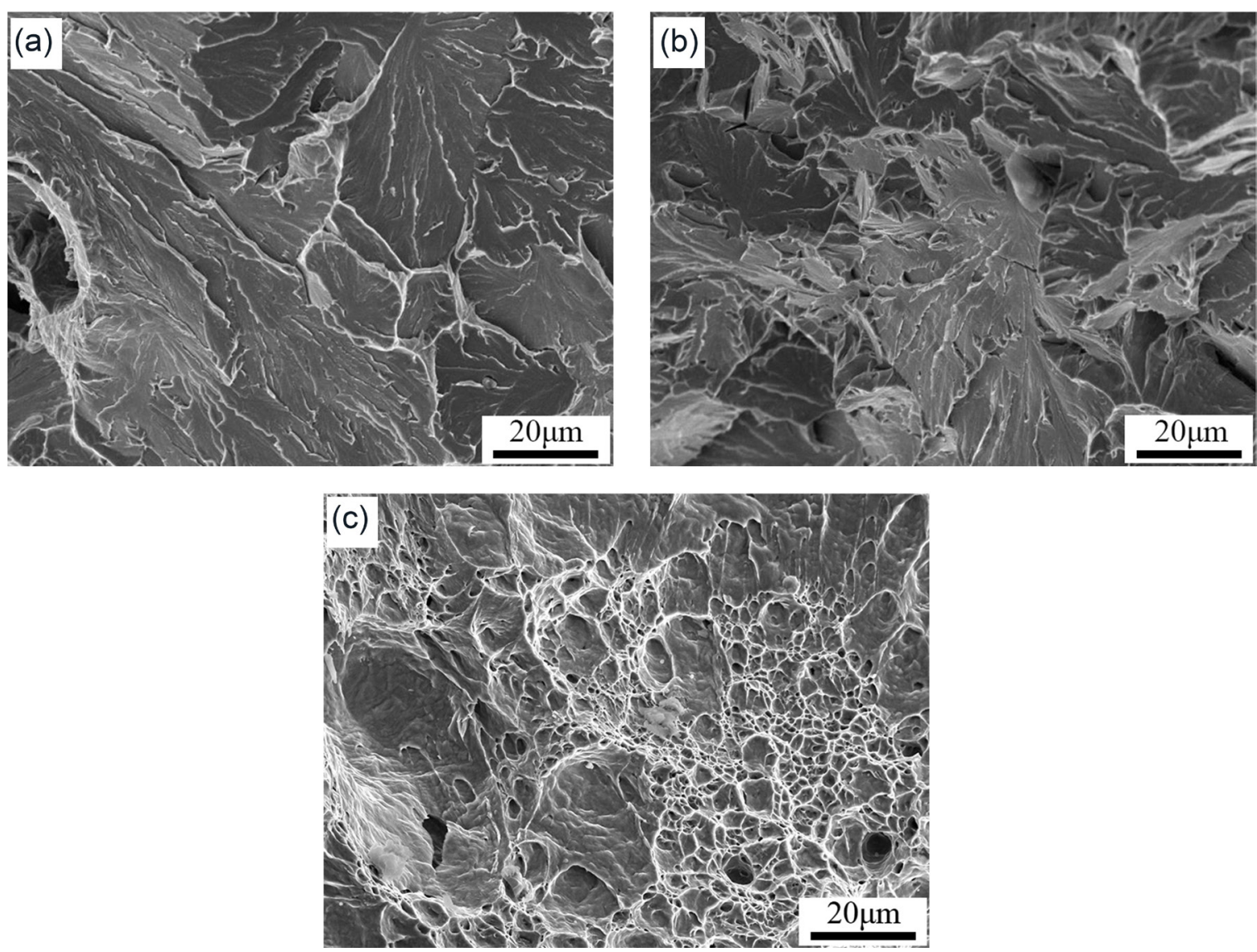

Figure 5. Impact fracture morphology of CGHAZ steel under different the welding heat input: (a) $18 \mathrm{~kJ} \cdot \mathrm{cm}^{-1}$, (b) $24 \mathrm{~kJ} \cdot \mathrm{cm}^{-1}$ and (c) $30 \mathrm{~kJ} \cdot \mathrm{cm}^{-1}$.

the mechanical properties of the specimens are better with the increase of heat input. The mechanical properties are the best when the welding heat input is $24 \mathrm{~kJ} \cdot \mathrm{cm}^{-1}$, which is ductile fracture. When the welding heat input is increased to $30 \mathrm{~kJ} \cdot \mathrm{cm}^{-1}$, the mechanical properties of the specimens are the worst, which is brittle fracture.

\subsection{Fracture analysis}

The impact fracture morphology of the above samples is shown in Figure 5. When the welding heat input is $18 \mathrm{~kJ} \cdot \mathrm{cm}^{-1}$ (as shown in Figure 5a), it is obvious that CGHAZ is a quasi-cleavage fracture with ductile fracture and brittle fracture coexisting, and the shear section ratio reaches $88 \%$. It can be seen from Figure $5 \mathrm{~b}$ that when the welding heat input is $24 \mathrm{~kJ} \cdot \mathrm{cm}^{-1}$, and it shows a ductile fracture mode. At this time, there are still a lot of dimples on the fracture surface, and there are small cleavage platforms with river patterns and a large number of ductile tearing bands with small dimples. The ductile tearing band at the interface of cleavage plane is helpful to dissipate energy in the process of crack propagation and crack arrest ${ }^{17}$. The existence of ductile fracture zone helps to obtain the higher impact toughness of quasi cleavage fracture with coexistence of ductile fracture and brittle fracture. However, when the welding heat input reaches $30 \mathrm{~kJ} \cdot \mathrm{cm}^{-1}$ (Figure $5 \mathrm{c}$ ), the size of cleavage surface in the fracture surface increases obviously. At this time, the tearing band is less, and the shear section ratio has been

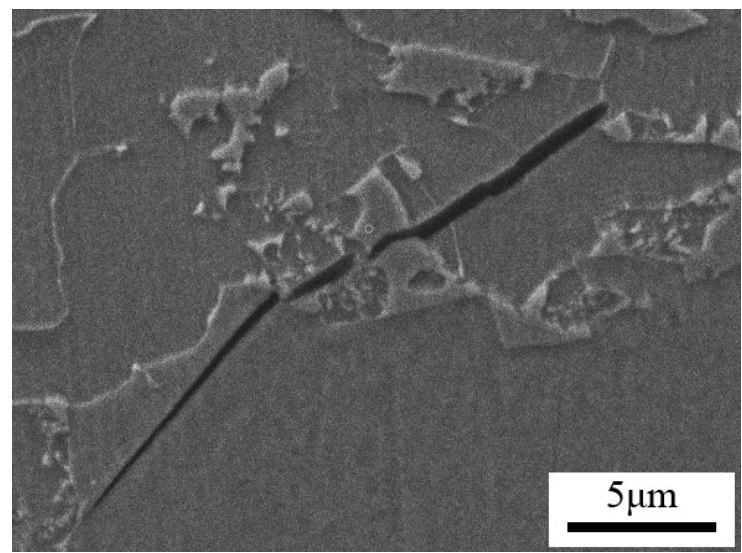

Figure 6. Typical secondary crack morphology of CGHAZ of test steel.

reduced to $24 \%$, which showing an obvious brittle fracture character. The results show that the plastic toughness of CGHAZ is the best when the welding heat input is $24 \mathrm{~kJ} \cdot \mathrm{cm}^{-1}$, followed by $18 \mathrm{~kJ} \cdot \mathrm{cm}^{-1}$, and the worst at $30 \mathrm{~kJ} \cdot \mathrm{cm}^{-1} 18$.

The propagation morphology of the secondary crack on the impact fracture surface is shown in Figure 6. According to the microstructure analysis of different linear energy, with the increase of linear energy, the grain size in CGHAZ is obviously coarsened, and the size of M-A component also increases. Moreover, the grain boundary has a blocking 
effect on the crack propagation process. Therefore, when the welding heat input is reduced, the smaller grain size is beneficial to obtain higher impact energy. In addition, due to the existence of M-A component, the microhardness is significantly higher than that of bainitic ferrite matrix ${ }^{19,20}$. When the local stress of M-A component exceeds its critical stress, microcracks formed at the interface between M-A component and bainitic ferrite matrix or formed by M-A component self-cracking will expand unsteadily and cause failure.

\section{Conclusions}

1. When the welding heat input is $18 \mathrm{~kJ} \cdot \mathrm{cm}^{-1}$, the microstructure of CGHAZ is mainly the lath bainite and granular bainite, and these structures are distributed alternately. When the welding heat input is $24 \mathrm{~kJ} \cdot \mathrm{cm}^{-1}$, the CGHAZ is mainly the lath bainite, and the bainite laths are parallel arranged in a certain orientation. When the welding heat input is $30 \mathrm{~kJ} \cdot \mathrm{cm}^{-1}$, the CGHAZ grains have obvious growth phenomenon and granular bainite. And the lath martensite decreases with the increase of temperature. With the increase of heat input, the grain size also grows.

2. When the welding heat input is $18 \mathrm{~kJ} \cdot \mathrm{cm}^{-1}$, the fracture mode of CGHAZ is the coexistence of brittle fracture and ductile fracture. When the welding heat input is $24 \mathrm{~kJ} \cdot \mathrm{cm}^{-1}$, there are a lot of dimples and ductile fracture morphology in CGHAZ fracture. However, when the welding heat input is $30 \mathrm{~kJ} \cdot \mathrm{cm}^{-1}$, the CGHAZ shows a brittle fracture character.

3. When $\mathrm{q} 420 \mathrm{qEN}$ steel is selected for welding structure, the welding heat input should be controlled at about $24 \mathrm{~kJ} \cdot \mathrm{cm}^{-1}$ by adjusting welding speed, welding voltage and welding current, so as to ensure the comprehensive mechanical properties of welded structure.

\section{Acknowledgements}

This research was financially supported through Shandong Provincial Natural Science Foundation, China (Grant No. ZR2016JL017).

\section{References}

1. Li JH, Chen YY, Ren XL, Zhang M. Microstructure and mechanical properties of submerged arc welding weld metal of ultra-low carbon bainitic steel. Mech Eng Mater. 2016;40:43-6.

2. Liu C, Zhao ZB, Northwood DO. Mechanical properties of heat affected zone in Bainitic high strength low alloy steel. Mater Sci Technol. 2002;18:1325-8
3. Jia KN, Jiang QY, Wang M. Influence of granular Bainite on toughness of high strength bridge steel welding rough crystal heat affected zone. Heat Treat Met. 2011;36:47-9.

4. Hamid M, Sasan Y, Behzad A, Naghi PA, Ali C, Yutao P. Microstructural and mechanical properties of low-carbon ultra-fine bainitic steel produced by multi-step austempering process. Mater Sci Eng A. 2018;734:329-37.

5. Ueki S, Matsumura T, Mine Y, Morito S, Takashima K. Microstructural fatigue crack growth in single-packet structures of ultra-low carbon steel lath martensite. Scr Mater. 2019;173:805.

6. Basiruddin SM, Chakrabarti SD. Chatterjee, Microstructural engineering and strength-impact toughness prediction in ultralow carbon bainitic steel. Mater Sci Technol. 2018;34:1910-8.

7. Chen JH, Cao R. Microscopic mechanism of cleavage fracture of weld metal. J Metall. 2017;53:18-35.

8. Wu YL, Jiao H, Yi R, Yang WD. Effect of heat input on microstructure and properties of FCAW joint of high strength weathering steel. J Welding. 2019;40:59-64. (Chinese).

9. Zhang M, Chen YY, Liu MZ, Li JH. Analysis on toughening mechanism of submerged arc welding joints of ultra-low carbon bainitic steel. J Weld. 2016;37:45-9. (Chinese).

10. Jiang QM, Zhang XQ, Chen LQ. Weldability of $1000 \mathrm{MPa}$ grade ultra-low carbon Bainitic steel. J Iron Steel Res. 2016;23:70510 .

11. Komura M. Shielded metal arc welding. J Jpn Weld Soc. 2010;79:158-65

12. Ale RM, Rebello JMA, Charlier J. A metallographic technique for detecting martensite-austenite constituents in the weld heat-affected zone of a micro-alloyed steel. Mater Charact. 1996;37:89-93.

13. Lan LY, Qiu CL, Song HY, Zhao DW. Correlation of martensiteaustenite constituent and cleavage crack initiation in welding heat affected zone of low carbon bainitic steel. Mater Lett. 2014; 125:86-8.

14. Hayashi T, Morito S, Ohba T. Local distribution of orientation relationship and microstructure evolution of lath martensite in an ultra-low-carbon steel. Scr Metall. 2020;180:1-5.

15. Poruks P, Yakubtsov I, Boyd JD. Martensite-ferrite interface strength in a low-carbon bainitic steel. Scr Mater. 2006;54:41-5.

16. Zhao L, Chen WZ, Zhang XD, Shan JG. Structure character of M-A constituent in CGHAZ of new ultra-low carbon bainitic steel under laser welding conditions. J Mater Sci Technol. 2006;22:382-6.

17. Lan LY, Qiu CL, Zhao DW, Gao XH, Du LX. Effect of single pass welding heat input on microstructure and hardness of submerged arc welded high strength low carbon bainitic steel. Sci Technol Weld Join. 2013;17:564-70.

18. Li ZS, Zhao XM, Shan DR. Impact toughness of subzones in the intercritical heat-affected zone of low-carbon bainitic steel. Materials. 2018;11:959-65.

19. Lan L, Qiu C, Zhao D, Gao X, Du L. Microstructural characteristics and toughness of the simulated coarse grained heat affected zone of high strength low carbon bainitic steel. Mater Sci Eng. 2011;529:192-200.

20. Lee SG, Sohn SS, Kim B. Effects of martensite-austenite constituent on crack initiation and propagation in inter-critical heat-affected zone of high-strength low-alloy (HSLA) steel. Mater Sci Eng A. 2018;715:332-9. 